\title{
ラップトップパソコンの液晶ディスプレイを光源に用いた光弾性法
}

松田 伸也*1

\section{Photoelasticity using liquid crystal display of laptop computer as light source}

\author{
Shinya MATSUDA ${ }^{* 1}$ \\ ${ }^{* 1}$ National Institute of Technology, Numazu College, Department of Mechanical Engineering \\ 3600 Ooka, Numazu-shi, Shizuoka 410-8501, Japan
}

\section{Received 9 September 2014}

\begin{abstract}
This paper presents photoelasticity using liquid crystal display (LCD) of laptop computer as light source for engineering education. First, angle of the polarizing axis in LCD was investigated using analyzer. Second, the photoelastic experiments were performed to acrylic rod using an LCD and commercially available educational photoelasticity device, respectively. As the results, the isochromatic line fringe pattern obtained using LCD was seen as well as that of the commercially available device. The photoleastic sensitivity values measured from these fringe patterns were good agreement. Therefore, the photoelasticity using LCD can be ensured a certain level of quantitativity. Moreover, the photoelastic experiments using polarizing lights of red $(\mathrm{R})$, green $(\mathrm{G})$ and blue $(\mathrm{B})$ primary colors of LCD were performed. Optical spectrums of the lights were also measured. As the results, it was confirmed that colors of the isochromatic line fringe patterns correspond directly to the each spectrums. In addition, it was shown that measurement of photoelastic constant and stress analysis can be performed on the basis of single fringe method using the polarizing light of $\mathrm{G}$ primary color. For using this method, it is important that the characteristics of polarizing lights of R, G and B primary colors is understood. Finally, the photolesticiy experiment using LCD was lectured to corporate engineers in open lecture of National Institute of Technology, Numazu College. The questionnaire results showed that the photolesticity experiment was an effectual method for mechanics of materials education since the corporate engineers admired for easy investigating a stress concentration. Photoelasticity using LCD denotes handy method which can be learned fundamental photoelasticity and mechanics of materials including association with characteristics of the lights because of LCD is given variety of polarizing lights.
\end{abstract}

Key words : Photoelasticity, Finge method, Liquid crystal display, RGB primary colors, Engineering education

\section{1. 緒言}

ガラスやプラスチックなど透明な等方性弾性体材料（光弾性体）は，外力が作用したとき光学的異方性が生じ るため複屈折現象を起こす。この性質は光弾性と呼ばれており，1816 年に D. Brewster によって発見された。 そ れ以来, 光弾性実験は材料の応力を解析する実験的手法として現在でも幅広く適用されている. 例えば, 加工さ れたプラスチック材料の残留応力評価（山川 他，2009）や疲労き裂進展中のき裂周りの応力場解析（Christopher， et al., 2008), 介在物周りの応力拡大係数解析（伊藤 他, 2004）などが行われている.さらに実用的な観点から, 自動車用電球の残留応力測定（鈴木 他，2011）やメガネのレンズ固定時におけるひずみ（鈴木 他，2010）・応力 分布測定（格内 他，2013）が行われている. また光弾性パラメータの取得から応力分布の解析まで自動化もされ ている（梅崎，2013）。他方で，近年では医療分野においても国内外で積極的に適用されている．例えば，模擬手 術中の脳血管壁面応力の評価（池田 他, 2008）や人工膝関節インサートの応力解析（廣川 他, 2009), インプラン トと骨との間の応力およびひずみ評価（Brosh, et al., 1998），インプラントで強化された総義歯の応力分布解析 （Kenney and Richards, 1998）などが行われている. したがって光弾性実験は，国内外問わず様々な分野で研究か ら実用まで幅広く行われており，グローバル化が進む現代では，高等教育機関や企業でのエンジニア育成におい

No.14-00456 [DOI: 10.1299/transjsme.14-00456], J-STAGE Advance Publication date : 16 January, 2015

${ }^{* 1}$ 正員，沼津工業高等専門学校（一410-8501 静岡県沼津市大岡 3600）

E-mail of corresponding author: matsuda@numazu-ct.ac.jp 
て光弾性実験は習得しておくべき手法と考えられる.

教育分野において光弾性実験は, 初等物理教育（例えば, 加藤, 2006）や力学教育（例えば, Shakerin and Jensen, 2001）において力の作用を可視化する際によく用いられている. また従来から高等教育機関において，材料力学 の工学実験では 2 次元光弾性実験から光弾性定数の測定や応力解析がしばしば行われている. 基本的な手法とし て, 光源（超高圧水銀灯やナトリウムランプなど，，偏光子，検光子および $1 / 4$ 波長板を組み合わせ，暗縞模様を 測定する単色フリンジ法および白色光を光源とするフリンジ法がある（辻 他, 1975). しかしながら, これら光源 や偏光器を設置して実験を行うためには場所や負荷方法が制限される. 光源の種類もまた制限されるため, 光の 特性と光弾性縞模様の関係はブラックボックスになりやすい.

近年, テレビやデスクトップまたはラップトップパソコンモニターとして液晶ディスプレイ (Liquid Crystal Display, 以下 LCD）が主流である. LCD は光源と偏光板を組み合わせて構成されているため, 画面の光は偏光 であることが知られている（例えば，藤掛，2008）。ゆえに，LCD の偏光を光弾性体に通して偏光サングラスや偏 光レンズ付きデジタルカメラなどで観察すれば，簡単に光弾性縞模様をin-situ 観察できる. その上，画面の色は RGB3 原色（R；赤， G ; 緑， B ; 青）を利用して表現されているため, 様々な色の偏光を得ることができる. 近 年は安価なパソコンが市場に多く出ており, 入手が容易であるため手軽に光弾性実験を行える. また, ラップト ップパソコンの中でも軽量かつ小型のモバイルパソコンは, 持ち運びが便利であり, 設置が容易である. その上, LCD の角度も調節できるため, さまざまな方向に対して偏光を与えることができる. したがって, 簡易的に光弾 性実験が可能であるため教育には最適なツールと考えられる. 若林（若林, 2006）は，パソコンの LCD を利用し て CD プラスチックケースやメガネのプラスチックレンズに生じる残留応力による光弾性縞模様や砂糖水の旋光 性の観察を紹介しており，初等物理教育としては十分適用できることを示している. Satoら (Sato, et al., 2009) もまた LCD を利用した光弹性実験を行い, 力の可視化を行っている. しかしながらいずれの研究も力の作用に よる光弾性縞模様の観察のみであり, 初等材料力学（光弾性と材料に作用寸る応力との関係）を対象とした定量 的な観点からは議論されていない. 特に, LCD の画面は RGB3 原色によって表示されているため, 白色光のみな らず 3 種類の $\mathrm{R} \cdot \mathrm{G} ・ \mathrm{~B}$ 原色光による光弾性実験も容易に行える. そのため工学教育上, 光の特性との関連性を 含めて基本的な光弾性と材料力学の関係を学ぶことができると予想され, 先に述べた問題点を解決できる可能性 があるため非常に興味深い. また LCD を光源として用いた光弾性実験を教育実践した事例は著者の知る限り存 在しておらず, 工学教育上の利点は定かではない.

そこで本研究では，ラップトップパソコンの LCD を光源に用いて，様々な色の偏光に対する光弾性実験を行 った．初めに市販されているラップトップパソコンの LCD の偏光特性について調查した．次に，LCD および市 販されている教育用光弾性実験装置を用いて曲げ静荷重を受けたアクリル材の光弹性縞模様をそれぞれ観察した. 得られた縞模様を用いてフリンジ法により測定した光弾性感度を比較し, 定量性について調査した. さらに, 曲 げ静荷重を受けたアクリル材に対して 3 種類の $\mathrm{R} ・ \mathrm{G} ・ \mathrm{~B}$ 原色光を利用した光弾性実験を行うとともに，それぞ れの分光スペクトルを測定した. これより，3 種類の原色光による縞模様とスペクトル分布の関連性を調査し， フリンジ法について検討した. 最後に, LCD を光源に用いた光弾性実験を企業技術者対象の公開講座で実践し, 受講者のアンケート結果から有用性を検討した.

\section{2. 光弾性実験の原理}

本節では文献（辻 他，1975）を参考にして光弾性実験の原理について簡単に論じる. 図 1（a）に示すように， 直線偏光が得られる偏光子 $\mathrm{P}_{1}$ と検光子 $\mathrm{P}_{2}$ の間に弾性限度以内で外力が作用した平面応力状態にある光弾性体平 板 $\mathrm{T}$ を配置した場合を考える：このとき，図 1 （b）に示すように $\mathrm{P}_{1}$ と $\mathrm{P}_{2}$ の偏光軸が互いに直交する状態を考え る. また $\mathrm{T}$ 内に作用する応力は互いに直交する主応力 $\sigma_{1}$ および $\sigma_{2}$ で表され， $\sigma_{1}$ と $\mathrm{P}_{1}$ の偏光軸とのな寸角度を $\theta$ とする. 光源から与えられる単色光が $\mathrm{P}_{1}$ を通過し, 変換された直線偏光が $\mathrm{T}$ を通過する. このとき, $\sigma_{1}$ および $\sigma_{2}$ の方向に分離して通過する 2 つの偏光によって位相差 $\delta$ を生じ, $\mathrm{P}_{2}$ から得られる偏光強度 $I_{0}$ は式（1）で表わさ れる. 


$$
I_{0}=A^{2} \sin ^{2}(2 \theta) \sin ^{2}\left(\frac{\delta}{2}\right)
$$

ここで，A は振幅である. また通過点の主応力差 $\sigma_{1}-\sigma_{2}$ と $\delta$ との間には次式のような関係がある.

$$
\delta=\frac{2 \pi w}{\lambda} C\left(\sigma_{1}-\sigma_{2}\right)
$$

$w$ は試験片の幅， $\lambda$ は使用光の波長， $C$ は光弾性定数（ブリュースターの定数）である. 式（1）より図 1 の場 合， $I_{0}$ は $\theta$ と $\delta$ に依存するため等色線と等傾線の双方が混在した光弾性縞模様が得られることを示している。乙 こで，図 2 (a) に示すように $\mathrm{P}_{1}$ と $\mathrm{P}_{2}$ の間に，2枚の $1 / 4$ 波長板 $\mathrm{Q}_{1}$ および $\mathrm{Q}_{2}$ を入れ，その間に $\mathrm{T}$ を配置する. $\mathrm{P}_{1}$ による直線偏光を $\mathrm{Q}_{1}$ により円偏光に変換し, $\mathrm{T}$ を通過後さらに $\mathrm{Q}_{2}$ によって直線偏光へ再変換して $\mathrm{P}_{2}$ を通過する.

このとき図 2 (b) に示すように, $\mathrm{Q}_{1}$ および $\mathrm{Q}_{2}$ の光軸は互いに直角で, $\mathrm{Q}_{1}$ の光軸と $\mathrm{P}_{1}$ の偏光軸とのなす角度を $\pi / 4$ $\operatorname{rad}$ とする. したがって $\mathrm{P}_{2}$ から得られる $I_{0}$ は,

$$
I_{0}=A^{2} \sin ^{2}\left(\frac{\delta}{2}\right)
$$

と表され, $\delta$ のみの関数となり $\theta$ に依存しない. ゆえに $\sigma_{1}-\sigma_{2}$ の大きさのみで決定され, 光弾性縞模様は明暗の 等色線のみが観察されることを示している. 式 (3) において, $\delta=2 \pi N(N=0,1,2, \cdots)$ のとき $I_{0}=0$ となり，暗視 野が得られる. 式（2）において $\delta$ を $2 \pi N$ と置き換えれば,

$$
N=\alpha\left(\sigma_{1}-\sigma_{2}\right) w
$$

となり，暗視野の縞次数 $N$ を測定することによって $\sigma_{1}-\sigma_{2}$ を解析できる. ここで $\alpha=C / \lambda て ゙ あ り$, 光弾性感度 である. $\alpha$ の逆数をとれば，フリンジ応力 $S$ となる．この方法は単色フリンジ法と呼ばれている. なお白色光の 場合，式（3）で示される単色光の集合なので偏光強度 $I$ は,

(a)

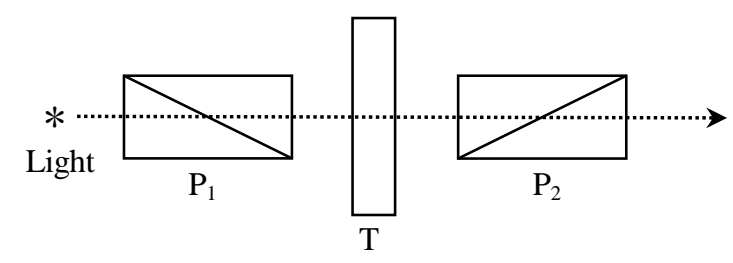

(b)

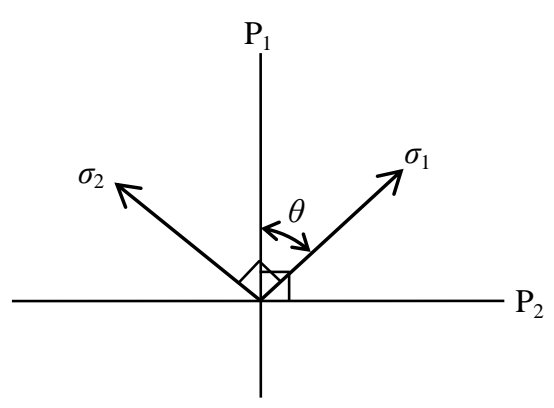

Fig.1 Figure 1(a) shows schematic of photoelasticity using polarizer $\mathrm{P}_{1}$ and analyzer $\mathrm{P}_{2}$ only, where $\mathrm{T}$ denotes photoelastic materials. Figure 1(b) shows relationship between polarizing axes of $\mathrm{P}_{1}$ and $\mathrm{P}_{2}$ and directions of principal stresses of $\sigma_{1}$ and $\sigma_{2}$ acting in $\mathrm{T}$ for figure 1(a), where angle between polarizing axis of $\mathrm{P}_{1}$ and $\sigma_{1}$ is $\theta$.

(a)

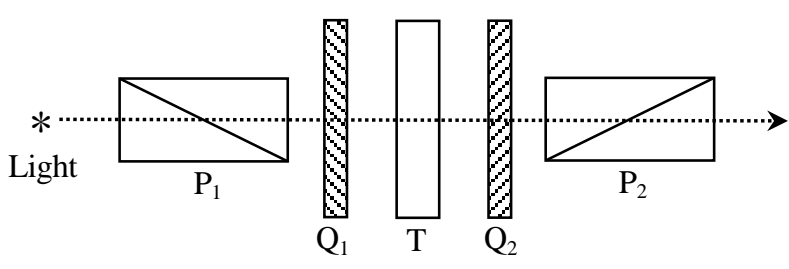

(b)

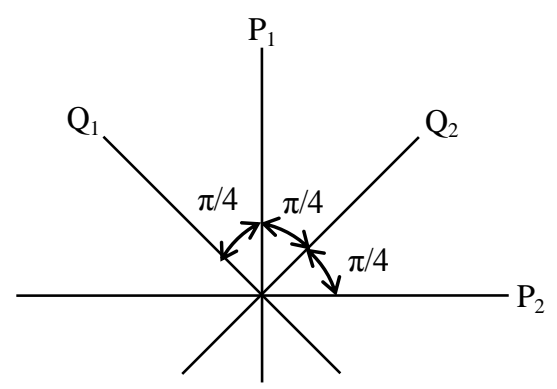

Fig.2 Figure 2(a) shows schematic of single fringe method, where $\mathrm{Q}_{1}$ and $\mathrm{Q}_{2}$ denote quarter wave plates, respectively. Figure 2(b) shows relationship between polarizing axes of $P_{1}$ and $P_{2}$ and optical axes of $Q_{1}$ and $Q_{2}$ for figure 2(a). 


$$
I=\sum I_{0}=\sum A^{2} \sin ^{2}\left(\frac{\delta}{2}\right)
$$

と与えられる。

\section{LCD の偏光特性と光弾性縞模様}

市販されているラップトップパソコン（Inspiron 15z UltrabookTM 15.6インチ，DELL 製）の LCD（偏光子） $\mathrm{P}_{1}$ と直線偏光板 $\left(125 \mathrm{~mm} \times 125 \mathrm{~mm} \times 0.2 \mathrm{~mm}\right.$ ，セルロースアセテートフィルム，ケニス製）（検光子） $\mathrm{P}_{2}$ を重袷わ せて観察した様子を図 3 にそれぞれ示す。なお観察は，検光子を通してデジタルカメラ（Power Shot S120, Canon 製）で行い，LCD の画面は白色とした. 図中の実線は $\mathrm{P}_{2}$ の偏光軸を示している. $\mathrm{P}_{2}$ の偏光軸の向きは市販され ている偏光サングラスと重ね合わせて観察することで確認した. 市販されている偏光サングラスの偏光軸の向き は水平面の反射光をカットするため垂直方向に設定されており，このことを利用している．図 $3(\mathrm{a})$ は， $\mathrm{P}_{2}$ の偏 光軸が水平となるように検光子を配置して観察した様子を示す。また図 3 (b) および (c) は, 図 3 (a) の状態 から検光子を左周りに $\pi / 4 \mathrm{rad}$ および $3 \pi / 4 \mathrm{rad}$ 方向へ回転させて観察した様子をそれぞれ示す. 図 3 (b) では最 も暗く, $\mathrm{P}_{1}$ の偏光軸は $\mathrm{P}_{2}$ の偏光軸と直交していることを意味する. 一方，図 3 (c) では最も明るく, $\mathrm{P}_{1}$ と $\mathrm{P}_{2}$ の 偏光軸の向きが一致していることを意味する。このことから本実験で用いたラップトップパソコンの LCD から 得られる偏光は直線偏光であり, 図 3 (b) に示すように $\mathrm{P}_{1}$ の偏光軸の方向は, $\pi / 4 \mathrm{rad}$ である. 他社のラップト ップパソコン (Endeavor, EPSON 製) の LCD についても同様に調査したところ，先に述べた結果と同様であっ た．若林（若林, 2006）の調査でも LCD の偏光軸の向きは先に述べた結果と同様であるが，一部では水平方向の LCD もあると報告している. したがって，パソコンの LCD は製品によって偏光軸の向きは異なることに注意が 必要である。

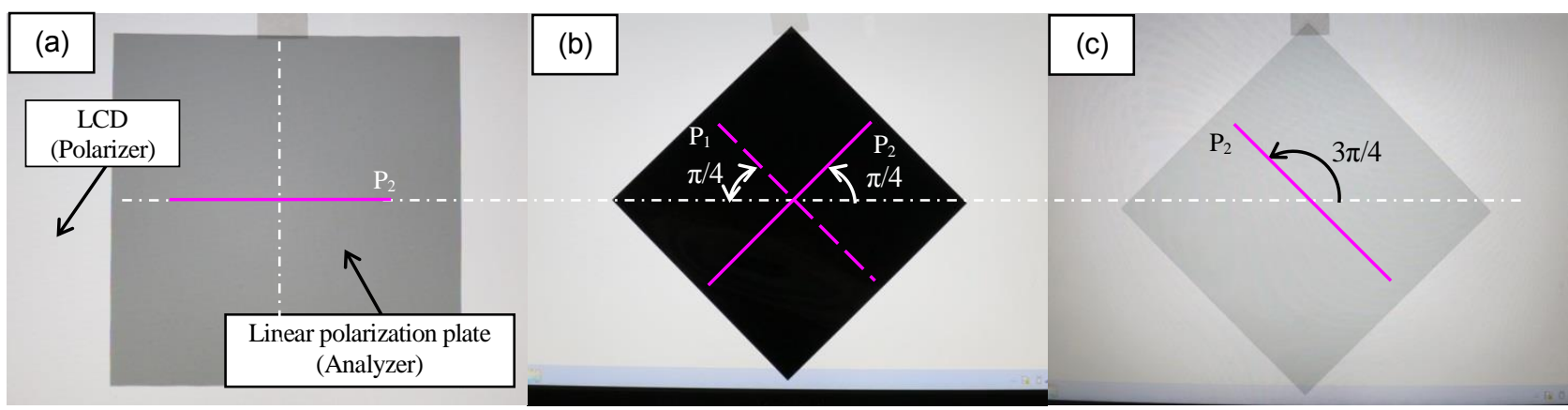

Fig.3 Characteristic of linearly-polarized light of white color given from LCD (polarizer) $\mathrm{P}_{1}$ was investigated using a linearly polarizing plate (analyzer) $\mathrm{P}_{2}$. When the linearly polarizing plate was turned counterclockwise $\pi / 4 \mathrm{rad}$ from a state of figure 3 (a), the linearly-polarized light was shaded. Therefore, polarizing axis of $\mathrm{P}_{1}$ was vertical to the polarizing axis of $\mathrm{P}_{2}$ in the shown figure $3(\mathrm{~b})$.
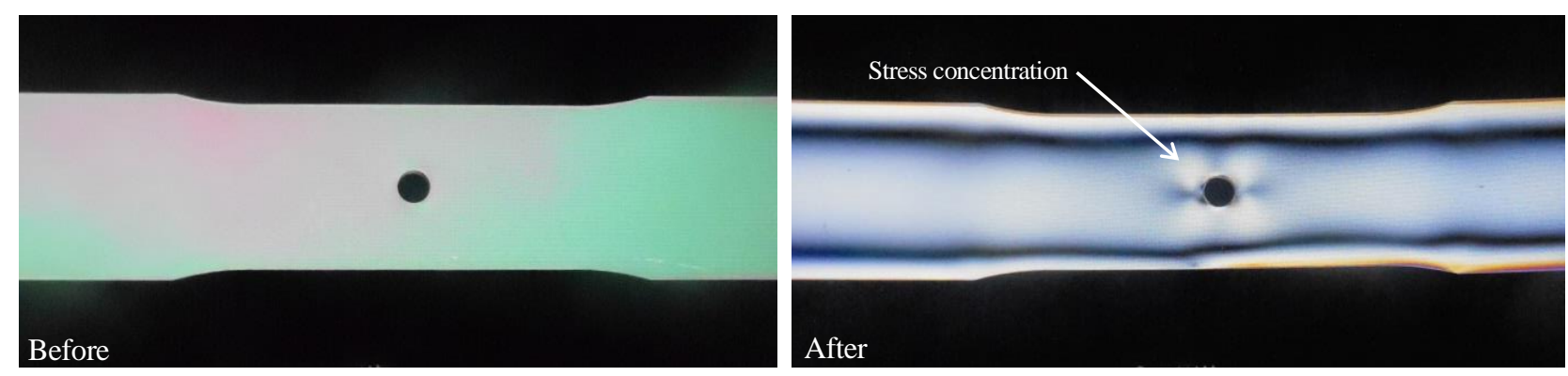

Fig.4 Photoelasticity using LCD was demonstrated in the shown figure. Photoelasticity fringe patterns for polycarbonate plate with a hole after annealing was undergone a color change compared to that before annealing. It was shown that residual stress acting in polycarbonate plate was removed. In addition, a stress concentration with deformation due to annealing was observed. 
図 4 にLCD を用いた光弾性の実例を示寸. 各写真は, 図 3 (b) に示寸状態での $\mathrm{P}_{1}$ と $\mathrm{P}_{2}$ の間に焼きなまし前後 の円孔を有するポリカーボネート（PC-1600，タキロン製）をそれぞれ配置して観察した光弾性を示す。ここでポ リカーボネートの焼きなましは, 文献（白石, 曾山, 1984）を参考に加熱炉を用いて $140^{\circ} \mathrm{C} て ゙ 5$ 時間加熱後, 炬冷 した. 焼きなまし前に比べて焼きなまし後の光弾性縞模様は変化しており, ポリカーボネートの残留応力の除去 が確認できる．また円孔周りには，焼きなましによる変形によって生じた応力集中も確認できる.

\section{4. 光弾性実験方法}

試験片の材料として,ホームセンターなど身近で入手できる市販のアクリル角材 (幅 $w=6.05 \mathrm{~mm} \times$ 厚さ $t=5.85 \mathrm{~mm}$ ) を用いた。 これを長さ $L_{\mathrm{long}}=170 \mathrm{~mm}$ および $L_{\mathrm{shor}}=50 \mathrm{~mm}$ に切り出してそれぞれ試験片とした.

図 5 (a) に精密万能試験機および LCD を用いた光弾性実験の様子を示す. 3 節で得られた知見を基に各偏光 器とパソコンを図 2 の状態に配置した. 荷重を与える試験機として, 長さ $L_{\mathrm{long}}$ の試験片では精密万能試験機 (AG-Xplus 5kN，島津製作所製），長さ $L_{\text {short }}$ の試験片では自作したてこ式の静荷重試験機を用いた. 負荷方法は，

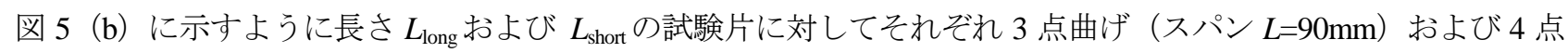
曲げ（上スパン $L_{1}=10 \mathrm{~mm}$ ，下スパン $L_{2}=30 \mathrm{~mm}$ ）で静荷重 $P$ を与えた。ここで荷重負荷および支点には平行ピン を用いた. パソコン，偏光子および検光子には，3 節で使用したラップトップパソコン（OS ; Windows 8) およ

(a)

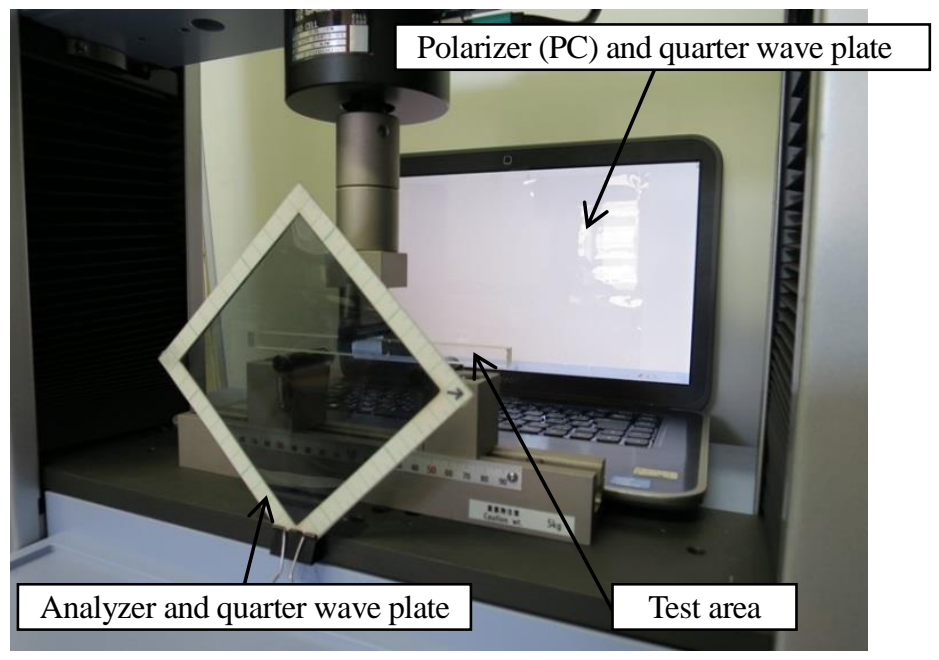

(b)

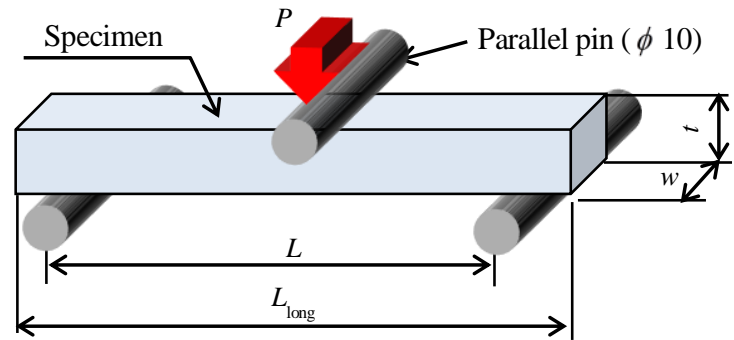

Three-point bending

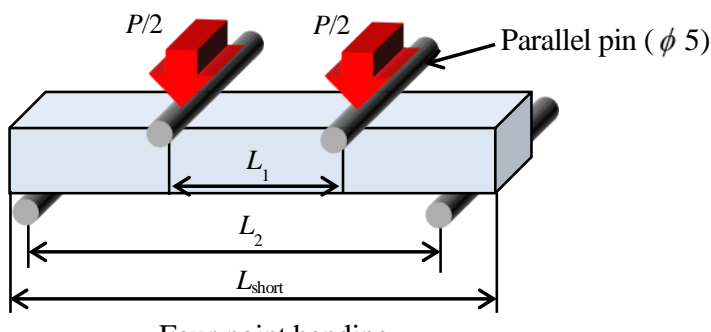

(c)

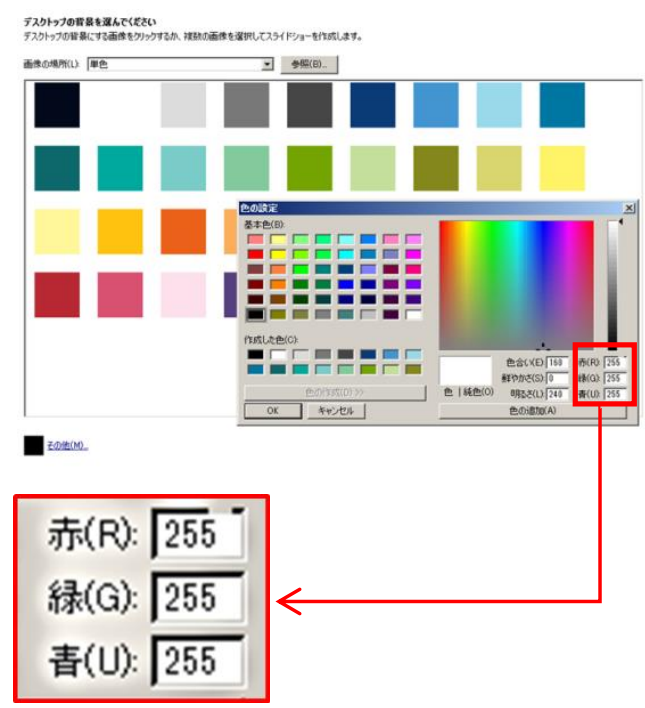

Fig.5 A photoelastic experiment using LCD is shown in the figure 5 (a). Three and four point bending loads were given to acrylic rods in the shown figure 5 (b), respectively. Colors of the desktop background were then changed using RGB tool shown in the figure 5 (c) for obtain polarized lights of white, red, green and blue colors. 


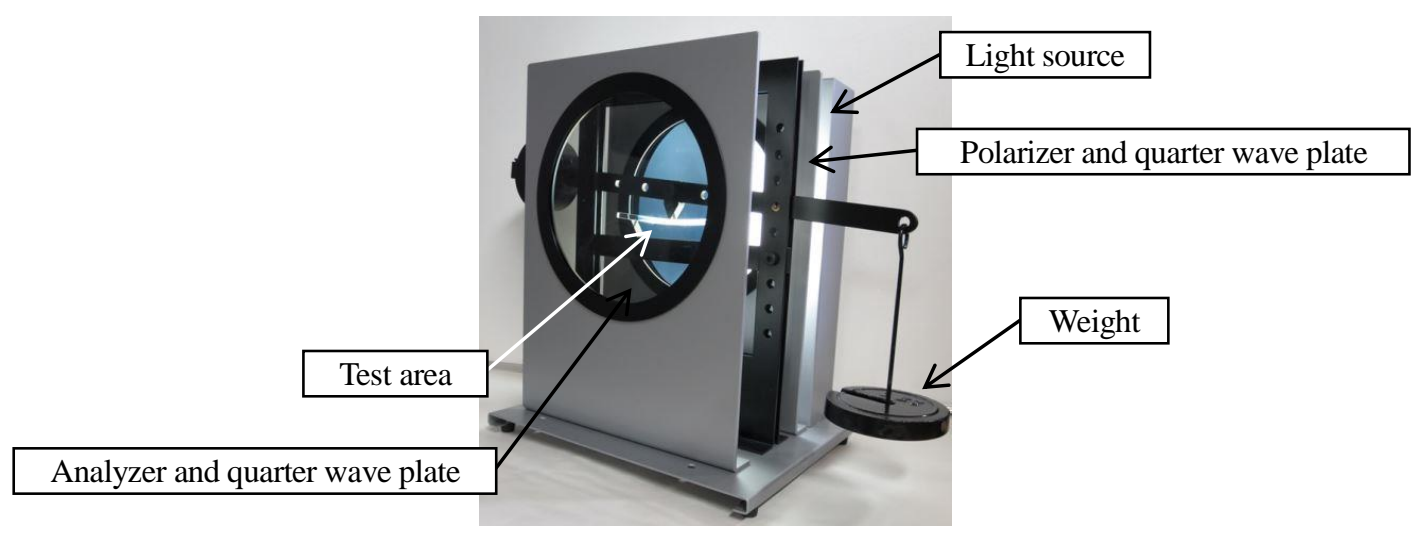

Fig.6 Commercially available educational photoelasticity device.

び直線偏光板を使用した.また円偏光を得るために, $1 / 4$ 波長板 (厚さ $45 \mathrm{~nm}$, 波長 $550 \mathrm{nn}$ に対する位相差值 $140 \mathrm{~nm}$, CR-140P, ポラテクノ製) を使用した. 偏光子側の 1/4 波長板は, セロハンテープを用いて PCに固定した. 一方, 検光子側は, 工作紙を用いて直線偏光板と一緒に挟み込み, 試験機に固定した. LCD の画面の色は図 5 (c) に示

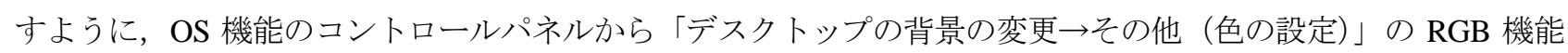
を利用して白色（(R）255，（G）255，（B）255）, 赤色（255，0，0），緑色 $(0 ， 255 ， 0)$ ，青色 $(0,0 ， 255 ）$ に それぞれ設定した. これより, 白色光および 3 種類の $\mathrm{R} ・ \mathrm{G} ・ \mathrm{~B}$ 原色光を用いて光弾性実験を実施した. 比較の ために図 6 に示寸市販されている教育用光弾性装置（簡易型光弾性実験装置 PE-200，理光研製）を用いた．市販 品は, 光源 (10W の蛍光管 3 本) と偏光子, 検光子および $1 / 4$ 波長板の基本的な偏光器で構成されている. 負荷 方法は，てこ式の 3 点曲げ静負荷方式である.ここで荷重負荷および支点には，装置付属の専用治具を用いてお り，負荷を与える先端の形状が平行ピンとは若干異なることを付記する.

\section{5. 実験結果および考察}

\section{$5 \cdot 1$ LCD および市販品を用いた光弾性実験}

図 7 に LCD および市販品を用いた光弾性実験から得られた 3 点曲げ静荷重 $(P=60 \mathrm{~N})$ に対する光弾性縞模様を それぞれ示す．ここで LCD の画面は白色である. また表 1 に白色光での光弾性による消光および透過される光 の模様の関係（辻 他, 1975）を示す．図７に示すように，いずれも応力が増加する方向へ順次，波長の長い光が 消えて変化する等色線が明瞭に現れており, 表 1 と対応していることが確認できる.またそれぞれを比較すると, 等色線の縞模様の様相は同様である.

図 8 に 3 点曲げ引張応力 $\sigma_{3 \mathrm{~b}}$ と等色線の縞次数 $N$ との関係をそれぞれ示す. ここで $N$ は, デジタルカメラから 撮影した光弾性縞模様の画像から数えた. その際に縞次数は, $\lambda=546.1 \mathrm{~nm}$ の単色光 (緑色光) に対する值とした. 使用した $1 / 4$ 波長板は，波長 $550 \mathrm{~nm}$ に対して位相差值 $140 \mathrm{~nm}$ なので十分対応している. 表 1 より $\lambda=546.1 \mathrm{~nm} に$ 対する縞次数は, 透過される赤色光と赤紫色光の間と対応しているが，赤色光と赤紫色光の区別は困難であった ため, 図 7 に示寸ように紫色光と赤色光の間を次数と考えて測定した. なお引張応力側端部までの次数は, 図 7 を例に説明すると，0 次から 1 次までの長さと 1 次から端部までの間の長さの割合から決定した．また $\sigma_{3 \mathrm{~b}}$ は初 等梁 (ベルヌーイ・オイラー梁) (例えば, ティモシェンコ 他, 1977) の 3 点曲げより,

$$
\sigma_{3 \mathrm{~b}}=\frac{3 P L}{2 w t^{2}}
$$

として評価した. 各文字は図 5 (b) と対応する. 図8 に示すように， $\sigma_{3 \mathrm{~b}}$ の増加に伴い $N$ は線形的に増加してい る. 図 8 から式 (4) を用いてそれぞれの $\alpha$ を測定した。このとき， $\sigma_{3 \mathrm{~b}}$ が作用する位置では $\sigma_{1}=\sigma_{3 \mathrm{~b}}, \sigma_{2}=0$ の ため $\alpha$ は,

$$
\alpha=\frac{N}{w \sigma_{3 \mathrm{~b}}}
$$


として与えられる. 測定した $\alpha$ 值および換算した $S$ 值を表 2 に示す. LCD および市販品から得られた $\alpha$ 值はそ れぞれ， $8.27 \times 10^{-3} \mathrm{~mm} / \mathrm{N}$ および $8.28 \times 10^{-3} \mathrm{~mm} / \mathrm{N}$ であり，両者の值はよく一致している. したがって，ラップトッ プパソコンの LCD を光源として用いた光弾性法によって定量性は十分に確保できる.ゆえにパソコンを準備し， 1/4 波長板および直線偏光板を購入するのみで, 安価でかつ簡易的に実験を行うことが可能である.またこの結 果からパソコンの LCD が与える直線偏光は高精度であると言える.

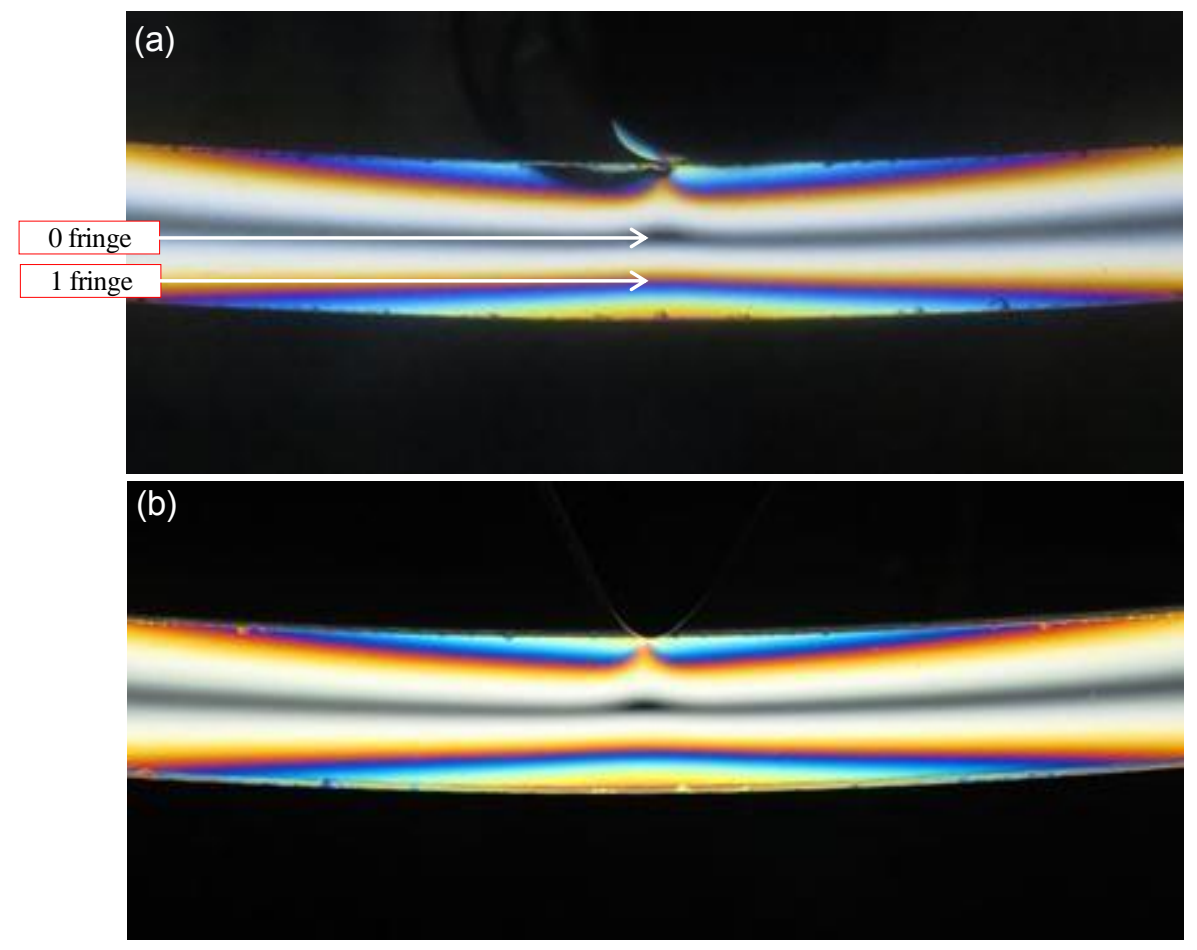

Fig.7 Isochromatic fringe patterns to 3-point bending load of $60 \mathrm{~N}$ were observed from photoelastic experiments using (a) LCD and (b) commercially available device. The isochromatic fringe pattern shown in figure 7(a) was exactly similar that shown in figure $7(\mathrm{~b})$.

Table1 Relationship between winked out light and penetrated light to optical path difference for light of white. (Data of table $4 \cdot 5$ from Tsuji, J., Nishida, M. and Kawata, K., Experimental methods in photoelasticity (1975) , p.94, THE NIKKAN KOGYO SHIMBUN,LTD. (in Japanese)).

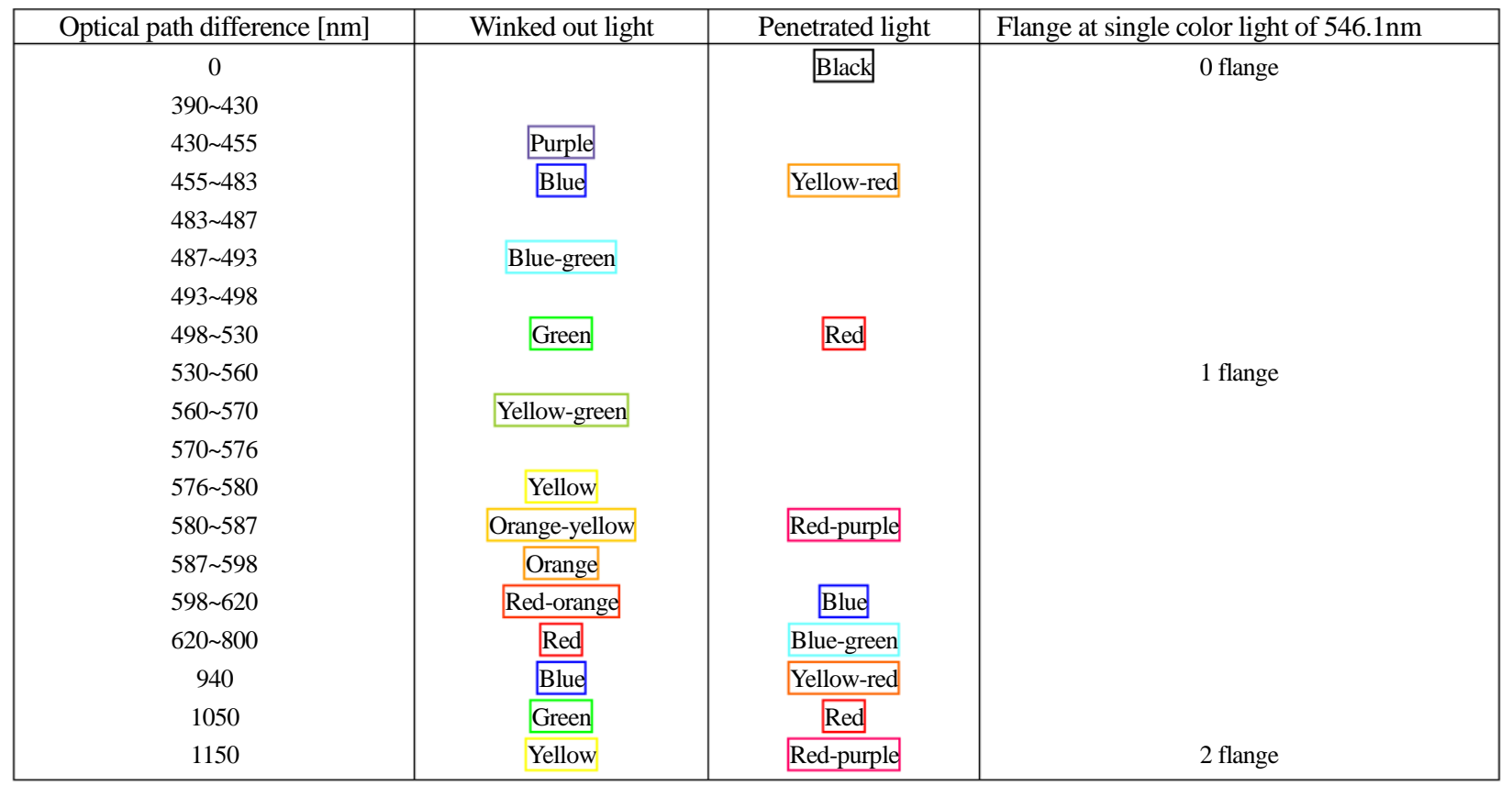




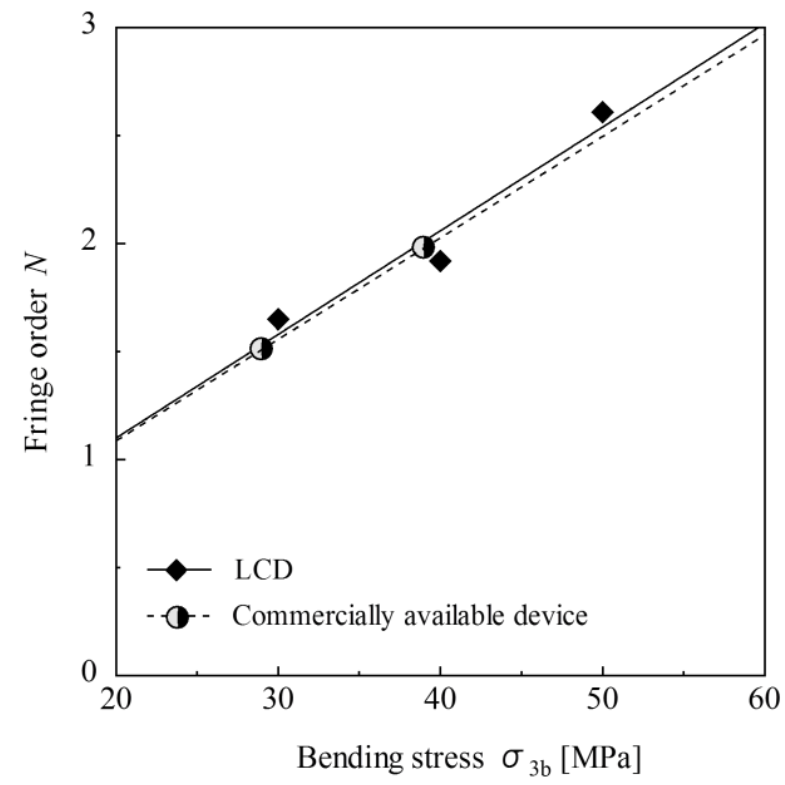

Table2 Values of photoelastic sensitivity and fringe stress for acrylic given using each photoelastic experiments.

\begin{tabular}{|c|c|c|}
\hline Device & LCD & $\begin{array}{c}\text { Commercially } \\
\text { available device }\end{array}$ \\
\hline $\begin{array}{c}\text { Photoelastic } \\
\text { sensitivity } \\
\alpha[\mathrm{mm} / \mathrm{N}]\end{array}$ & $8.27 \times 10^{-03}$ & $8.28 \times 10^{-03}$ \\
\hline $\begin{array}{c}\text { Fringe stress } \\
S[\mathrm{~N} / \mathrm{mm}]\end{array}$ & 120.92 & 120.77 \\
\hline
\end{tabular}

Fig.8 Plots of fringe order and 3-point bending stress obtained from each photoelastic experiments.

\section{$5 \cdot 23$ 種類の $R \cdot G \cdot B$ 原色光を用いた光弾性実験 \\ $5 \cdot 2 \cdot 1$ 光弾性縞模様と分光スペクトル}

図 9 に 3 種類の $\mathrm{R} \cdot \mathrm{G} ・ \mathrm{~B}$ 原色光によって得られた 4 点曲げ静荷重（ $P=379 \mathrm{~N} ）$ に対する光弾性縞模様を示す. 比較のために，白色光を用いた場合も示す．白色光の場合，前節で述べたようにいずれも応力が増加する方向へ 順次, 波長の長い光が消えて変化する等色線が明瞭に確認できる. 一方, $\mathrm{G}$ 原色光の場合は図 9 （b）に示すよう に, 中立軸の暗 (黒色) 縞模様から始まり，黄緑色および緑色の縞模様と暗縞模様が観察された。他方で， $\mathrm{R}$ 原 色光の場合は図 9 （c）に示寸ように, 中立軸の暗縞模様から始まり, 応力が増加する方向一順次, オレンジー赤 紫の順に繰返し変化する色付いた縞模様のみが観察された. また図 $9(\mathrm{~d})$ に示すように B 原色光の場合もまた, 中立軸の暗縞模様で始まり, 薄い紫 $\rightarrow$ 水色 $\rightarrow$ 青色の順で赤色と同様に繰返し変化する色付いた縞模様の夕が観察 された．Rおよび B 原色光のいずれも， $\mathrm{G}$ 原色光のような暗縞模様は観察されなかった.

図 10 に分光器で測定した白色光および $\mathrm{R} \cdot \mathrm{G} \cdot \mathrm{B}$ 原色光から得られた分光スペクトルおよび代表的な可視光の スペクトルを色別で示す. 分光器には, 浜松フォトニクス製のミニ分光器（C11007MA）を用いた. 縦軸の A/D カウントは, 光強度と比例する值である. 図 10 に示すように, 白色光は $\mathrm{R} \cdot \mathrm{G} \cdot \mathrm{B}$ 原色光の重㸚わせになって いる. $\mathrm{R} \cdot \mathrm{G} ・ \mathrm{~B}$ 原色光のスペクトルは，いずれもピーク值 $(\mathrm{R} ; 592.3 \mathrm{~nm}, \mathrm{G} ; 539.1 \mathrm{~nm}, \mathrm{~B} ; 453.4 \mathrm{~nm})$ が見られ るが，広範囲に渡って分布している．特に $\mathrm{R}$ 原色光のスペクトルは，ピーク值が橙色で示しており，また $450 \mathrm{~nm}$ 前後でも分布しているため, 紫色光や青色光も含んでいる. したがって $\mathrm{R} \cdot \mathrm{G} \cdot \mathrm{B}$ 原色光は, 一見それぞれ赤色, 緑色, 青色のピーク值が高いため単色光に見えるが, 実際は白色光と同様に他の色が混ざって表現されている. 室谷（室谷, 2012）もまた，パソコンの LCD の色はすべての色が正しく再現されているわけではないと論じてい る. したがって, 白色と同様に 3 種類の $\mathrm{R} \cdot \mathrm{G} \cdot \mathrm{B}$ 原色光の偏光強度は, 各スペクトルの偏光強度の総和で決定 されるため式 (5) で表される. そのため, 図 9 に示す $\mathrm{R} \cdot \mathrm{G} \cdot \mathrm{B}$ 原色光に対する等色線縞模様は複数の色から構 成されており, 図 10 の $\mathrm{R} \cdot \mathrm{G} ・ \mathrm{~B}$ 原色光のスペクトルとおおよそ対応していることがわかる. 実際, 図 9 に示寸 等色線はデジタルカメラで撮影しているため, デジタルカメラの CCD 素子のスペクトル応答にも依存している. そのため, 図 9 の等色線と図 10 のスペクトル分布が完全には一致しないことを付記する.

ここで図 9 (b) に示すように $\mathrm{G}$ 原色光の場合は黄緑色および緑色の縞模様と暗縞模様を示しており, 単色光を 用いたときの傾向と類似している. このことは, 表 1 に示寸白色光の消光と透過される光から定性的に説明でき る. 緑色が消える波長では赤色光が透過されるが，図 10 に示したように $\mathrm{G}$ 原色光は赤色光のスペクトルは持た ない，そのため暗縞模様が現れる. 図 9 (a) に示寸白色光の縞模様と比較したとき, 白色光において赤色縞模様 が見られる位置において $\mathrm{G}$ 原色光では暗縞模様となっていることからも明らかである.したがって本実験で使用 したラップトップパソコンの場合，緑色の波長を用いて単色フリンジ法が適用できると考えられる. 


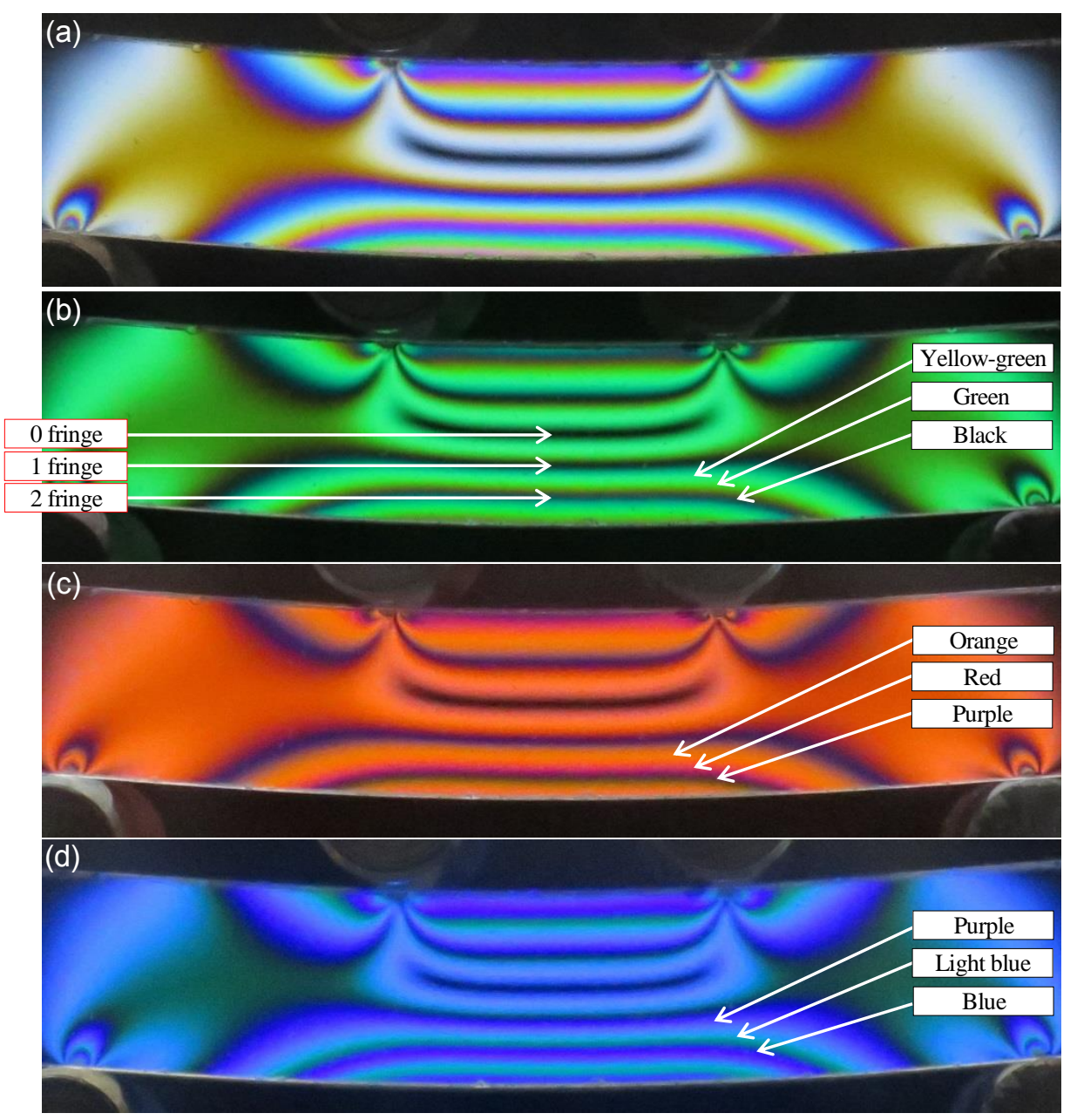

Fig.9 Isochromatic fringe patterns for 4-point bending load of $379 \mathrm{~N}$ were observed from photoelastic experiments using polarized lights of (a) white, (b) green, (c) red and (d) blue colors of LCD.

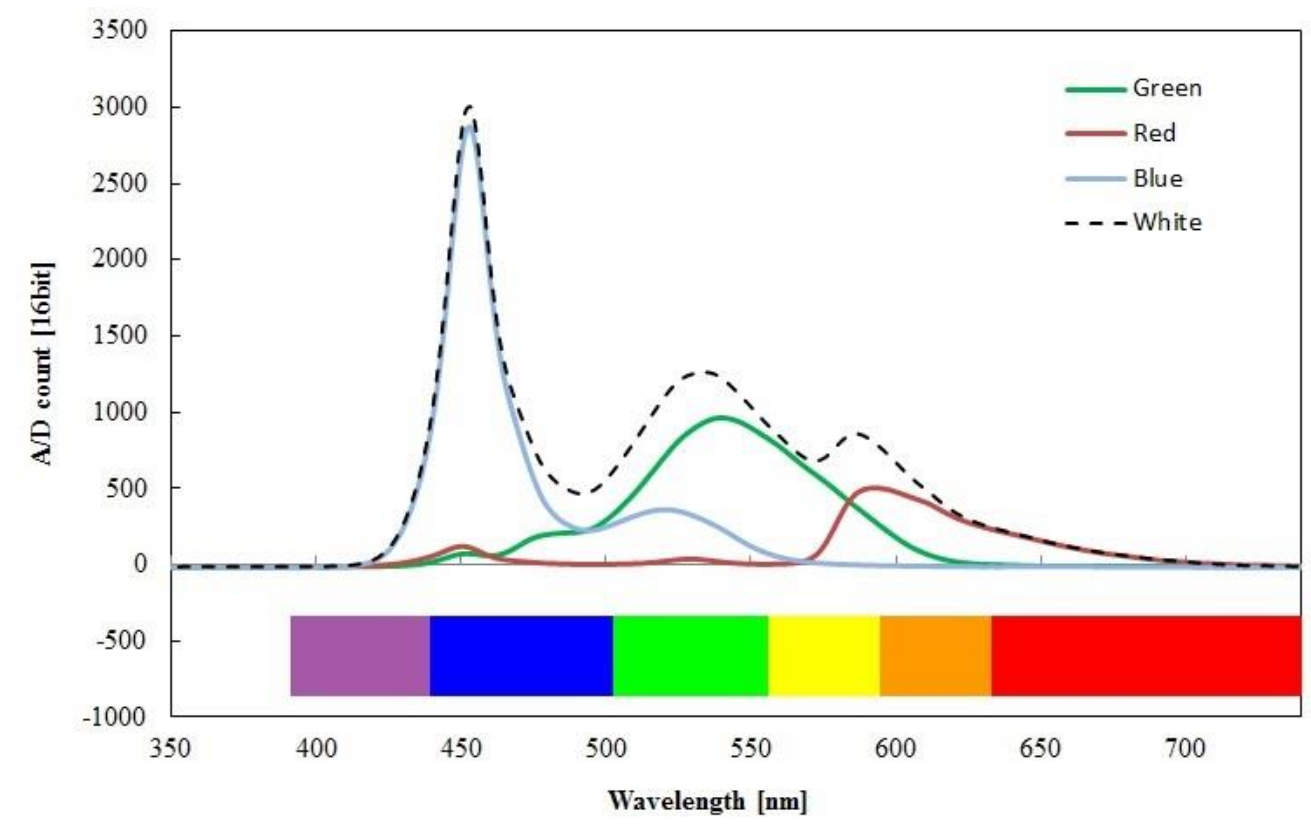

Fig.10 A/D count vs wavelength diagrams for polarized lights of green, red, blue and white colors obtained from LCD and spectrum distribution of typical optical wavelength. 


\section{$5 \cdot 2 \cdot 2$ 光弾性定数の測定と応力解析}

前節で論じたことを検証するため, $\mathrm{G}$ 原色光を用いた光弾性実験により $C$ 值の測定を行った. 図 11 に 点曲 げ引張応力 $\sigma_{4 \mathrm{~b}}$ と $N$ との関係を示す.ここで縞次数は，図 9 （b）に示すように暗縞模様を数えた. その際，引張 応力側端部での次数は， $5 \cdot 1$ 節で述べた方法で測定した。 また $\sigma_{4 \mathrm{~b}}$ は，初等梁の 4 点曲げより，

$$
\sigma_{4 \mathrm{~b}}=\frac{3 P\left(L_{2}-L_{1}\right)}{2 w t^{2}}
$$

として評価した. 各文字は図 5 （b）と対応する. 図 11 に示すように $\sigma_{4 \mathrm{~b}}$ の増加に伴い縞次数は線形的に増加し ている. 図 11 から式 (4) を用いてそれぞれの $\alpha$ を測定した. このとき， $\sigma_{4 \mathrm{~b}}$ が作用する位置では $\sigma_{1}=\sigma_{4 \mathrm{~b}}, \sigma_{2}=0$ のためCは,

$$
C=\frac{\lambda N}{w \sigma_{4 \mathrm{~b}}}
$$

として求められる.ここで, $\lambda$ は図 10 から得られたピーク值の $539.1 \mathrm{~nm}$ を用いた. 算出した $C$ は $5.17 \times 10^{-6} 1 / \mathrm{MPa}$ であった。 この值は，一般的に知られているアクリルの值 $6 \times 10^{-6} 1 / \mathrm{MPa}$ (例えば，今井 他, 2000）とおおよそ一

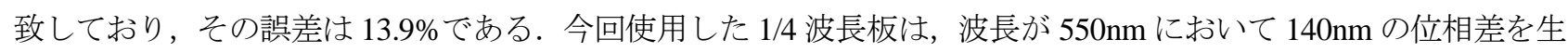
じる波長板である.図 10 から得られた $\mathrm{G}$ 原色光の波長のピーク值は 539.1nm であり，使用した波長板とほぼ対 応している. そのため波長板の影響はほとんど受けない. したがって主な原因として，式（9）から理解できるよ うに光弾性定数は，測定した $\lambda$ 值と $N$ 值の影響を受けたと考えられる. LCD の G 原色光は完全な単色ではない ため， $N$ 值の測定精度が十分でないことが挙げられる．それに伴い，本実験よりさらに高次の縞次数を測定する 場合はその影響をさらに受けると予想される，それに加えて $\lambda$ 值は，図 10 に示した分光器を用いて LCD から測 定したピーク值を用いたが，前節で論じたように図 9 に示す等色線はデジタルカメラで撮影しているため，縞模 様はデジタルカメラの CCD 素子のスペクトル応答にも影響を受けている. そのため, デジタルカメラから得ら れる $\lambda$ 值が LCD から得た $\lambda$ 值と緑色波長の範囲において異なり, 図 10 で撮影した $N$ 值の測定に影響が表れたこ とも原因の 1 つとして考えられる.

さらに得られた $C$ 值を用いて, 図 5 （b）に示す 3 点曲げを受けたアクリル試験片の応力を $\mathrm{G}$ 原色光による光

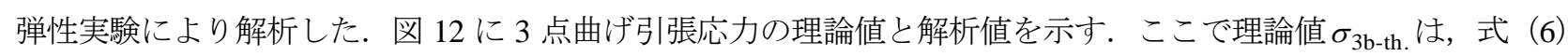
より与えた. 解析した応力 $\sigma_{3 \mathrm{~b} \text {-analysis }}$ は, 式（9）において $\sigma_{4 \mathrm{~b}}$ を $\sigma_{3 \mathrm{~b} \text {-analysis }}$ に置き換えることで,

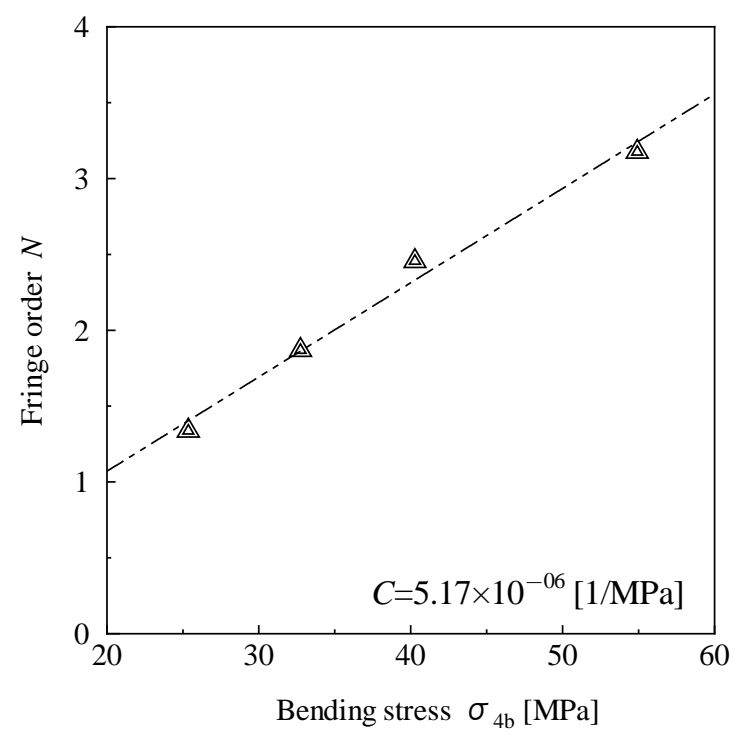

Fig.11 Plots of fringe order and 4-point bending stress obtained from photoelastic experiment using polarized lights of green color.

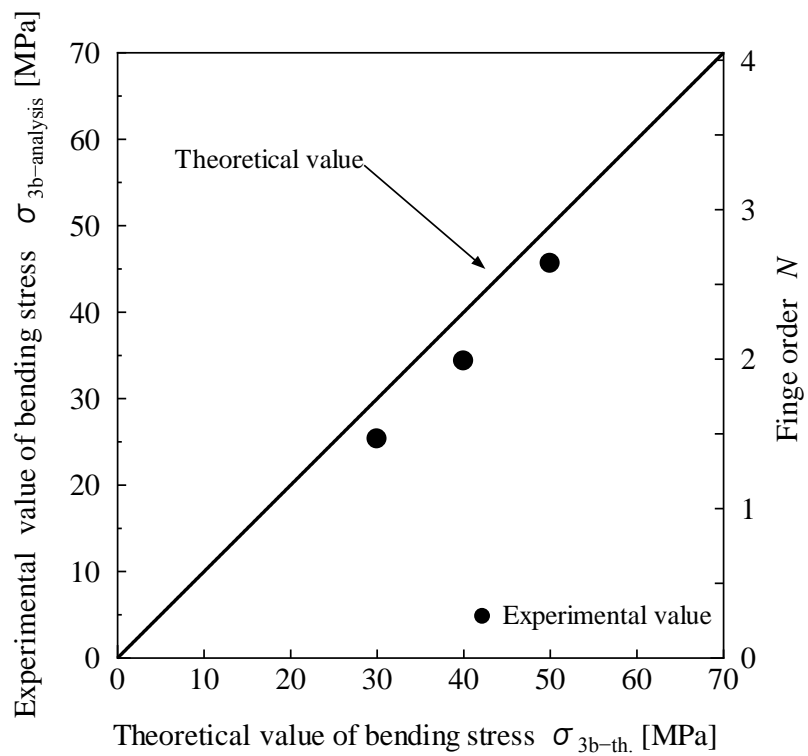

Fig.12 An example of stress analysis with the aid of photoelastic experiment using polarized lights of green color. (Plots of experimental and theoretical values of three-point bending stresses.) 


$$
\sigma_{3 \mathrm{~b}-\text { analysis }}=\frac{\lambda N}{w C}
$$

として求めた。 なお $N$ 值は先に述べた方法と同様に，3 点曲げによる等色線縞模様から観察される暗縞模様を数 えた. その際, 図 11 に示した $N$ 值の範囲内で $N$ 值を測定できるように荷重を与えた. 図 12 に示すように解析值 と理論值はおおよそ一致しており，その誤差は平均して $12.8 \%$ であ. 理論值と解析值の誤差の原因として，式

（9）と式（10）の比較から理解できるように， $N$ 值の測定精度が挙げられる. 平行ピンで 3 点曲げ荷重を負荷 しているため, サンブナンの原理により引張応力側の応力集中が若干緩和されていることが原因の一つとして考 えられる.ただし, 荷重支点から評価応力までの距離は十分あるので, その影響は小さい. そのため主な原因と して, LCD の G 原色光は完全な単色ではないことに関連すると考えられる. 以上の結果より, ある程度の精度を 確保して光弾性定数の測定および応力解析が可能であり, 先に述べたことの妥当性を検証した. パソコンの LCD を光源として用いることで, 様々な光に対する光弾性が得られ, 光の特性との関連性を含めて基本的な光弾性と 材料力学の関係を定量的な観点から学ぶことができる. ゆえに 2 節で論じた光弾性実験の原理もより深く理解す ることができると考えられる.

\section{LCD を光源として用いた光弾性実験の教育実践}

2013 年 9 月 5 日（木）（13:00～17:00）に沼津高専において，公開講座「材料強度学入門～金属疲労の基礎知識 と光を利用した力の可視化」（定員 10 名）を企業技術者に対して実施した. 受講者は，6名（機械系技術者 5 名， 鋳造専門技術者 1 名）であった。受講者は，平日の開催であることを考えれば，事業と関連した基礎的内容のた め会社におけるエンジニア育成教育の一環として参加されたと推察される，本講座では，まず初めに金属疲労現 象の基礎的な特性について講義を行い, 疲労試験の実演および走査型電子顕微鏡による疲労破面観察を実施して 破壊原因を調査する手法を説明した，その後，機械構造物の疲労破壊では，応力集中が破壊の起点となることが 多いため, 応力集中箇所を特定するための手法として光弾性実験の基本原理を講義するとともに実演を交えて説 明した. 図 13 に光弾性実験の実演の様子を示す. 初めに, 図 6 に示した市販の光弾性装置を用いて，図 13 (a) に示すように各コーナー部の曲率半径が異なるコの字型モデルに生じる光弾性縞模様を観察し, 曲率半径と応力 集中の関係を説明した，その後，光弾性実験の簡易的な手法として LCD を光源として用いた光弾性実験を実施 した. 3 節で論じたようにノートパソコンと直線偏光板のみを用いて, CD プラスチックケースやプラスチック製 保護メガネの実験を実施し, 生じている残留応力や応力集中と光弾性縞模様の関係を説明した. その際, LCD 画 面の色を変えることで，様々な光弾性縞模様を表現することで光特性との関連性も説明した. さらに，図 13 (b) に示すように実際に円孔（ $\phi 10 ）$ を有するポリカーボネートの引張試験を実施し, 引張荷重に伴う円孔周りの光 弾性縞模様の変化を観察した。 このとき $1 / 4$ 波長板は用いておらず, 受講者に直線偏光板を配布して実際に観察

(a)

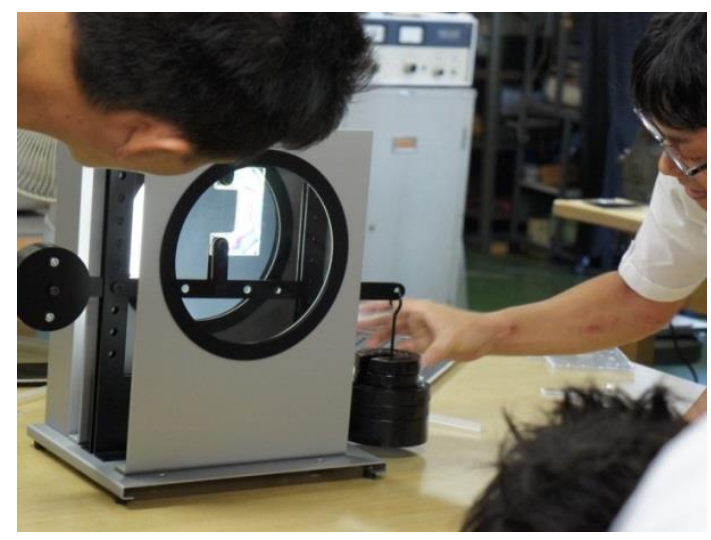

(b)

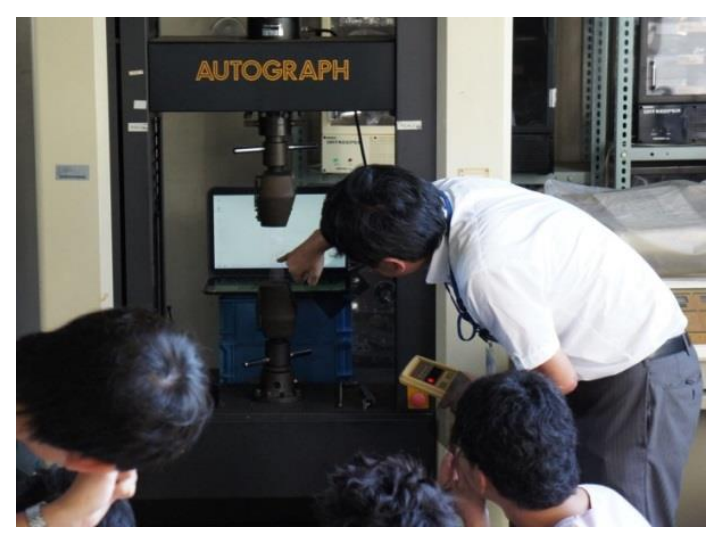

Fig.13 In Thursday, September 15, 2013, National Institute of Technology, Numazu College held an open lecture on basic knowledge of fatigue of metals and visualization of force by photoelasticity. Figures are shown appearance of the open lecture. The participants observed photoelasticity fringe patterns due to stress concentration by photoleasticity experiments using (a) commercially available educational photoelasticity device and (b) LCD. 
していただいた．本講座の最後にアンケートを実施した．光弾性実験に対するアンケートとして，「LCD を用い た光弾性実験は, 今後お仕事関係などにおいて少しでも役に立ちそうな内容でしたか.」との質問に 6 名中 5 名(機 械系技術者 4 名，材料系技術者 1 名）から「はい」の回答を得た。さらに，「はい」と回答をいただいた受講者か らコメントをいただいた。 以下に抜粋して示す.

1）金属等実際に実験を行えないものでも透明の樹脂のモデルを作れば簡単に実験を行えるため, 部品が壊れ て強度を上げたいときの対応と効果を調べるときなどにやってみようと思いました。（機械系技術者）

2) 金属疲労に関して提案が出来ると思います。(鋳造技術者)

3）簡易的に応力集中の場所がわかるので，ちょっとしたときに役立ちそう。(機械系技術者)

得られたコメントの共通点として，身近な製品を用いて応力集中を容易に特定できることが受講者に対して有 益な情報となっている．企業技術者にとっては，簡易的な形状設計対策など課題解決のための便利なツールと考 えていることも読み取れる. したがって，LCD 光源に用いた光弾性実験は，身近な製品を用いて応力集中を容 易に特定できるため材料力学教育ツールとして利点がある. 本論文で示した手法によって光弾性感度・光弾性定 数の測定や応力解析を行えば, 形状設計や金属疲労対策と関連して定量的な観点からもその効果はさらに期待で きると考えられる.

\section{7. 結 言}

本研究では, ラップトップパソコンの LCD を光源に用いて白色光および 3 種類の $\mathrm{R} \cdot \mathrm{G} \cdot \mathrm{B}$ 原色光による光弾 性実験を行い，定量的な観点から論考した．さらに，公開講座において企業技術者を対象として光弹性実験の教 育を実践した。 その要約を以下に示す.

1. 白色光を光源とした LCD および教育用光弾性装置を用いて測定したそれぞれの光弾性感度の值はほぼ一 致した.

2. $\mathrm{R} \cdot \mathrm{G} \cdot \mathrm{B}$ 原色光による等色線縞模様の色は, LCD から得られるスペクトル分布と対応していることを確 認した.

3. $\mathrm{R} \cdot \mathrm{G} ・ \mathrm{~B}$ 原色光の偏光特性を把握した上で適切な原色光を選択寸ることで, ある程度の定量性を確保し た光弾性定数の測定および応力解析ができることを示した.

4. 公開講座アンケート結果より, LCD を用いた光弾性実験は簡易性が評価されており, 企業技術者にとって 身近な製品によって応力集中を容易に特定できるため有益な情報を与えた.

\section{謝 辞}

本論文を発表するにあたり, 沼津高専機械工学科 5 年生の宮川綾音さん（現，東プレ）には光弾性実験および データ解析に取り組んでいただいた. ここに感謝の意を表する. また本研究の一部は学内経費平成 25 年度校長リ ーダーシップ経費の助成を受けたものである.

\section{文献}

Brosh, T., Pilo, R. and Sudai, D., The influence of abutment angulation on strains and stresses along the implant/bone interface: Comparison between two experimental, The Journal of Prosthetic Dentistry, Vol.79, No.3 (1998), pp.328-334.

Christopher, C.J., James, M.N, Patterson, E.A. and Tee, K.F., A quantitative evaluation of fatigue crack shielding forces using photoelasticity, Engineering Fracture Mechanics, Vol.75 (2008), pp.4190-4199.

藤掛英夫, 液晶材料/ディスプレイの現状と課題, 照明学会誌, Vol.92, No.10 (2008), pp.721-728.

廣川俊二, LAWI Ansarullah, 関屋圭輔, 瀧口純一郎, 高・深屈曲対応型人工膝関節インサートの光弾性応力解析, 日本機械学会論文集 C 編, Vol.75, No.752 (2009), pp.1016-1025.

池田誠一, 岡田雄太, 福田敏男, 新井史人, 根来眞, 高橋郁夫, 脳血管内手術シミュレーションのための個別型脳 血管立体モデル：第 3 報,光弾性法による血管壁面応力の模擬術中計測, 日本機械学会論文集 $\mathrm{C}$ 編, Vol.74, No.743 (2008), pp.1914-1919.

伊藤秀明, 西村健太郎, 江角務, 回転円板中のき裂先端の変形に及ぼす介在物の機械的性質 : 光弾性法とコース 
ティックス法による実験的検討，日本機械学会論文集 A 編, Vol.70, No.699 (2004), pp.1609-1615.

今井哲也, 志田宜義, 菅圭二, 飯田哲哉, 薄型基板における複屈折制御の検討, PIONEER R\&D, Vol.10, No.3 (2000), pp.22-28.

格内敏, 徳田直子, 金子弘, 西村淳, めがねのレンズ固定がレンズひずみに及ぼす影響, 実験力学, Vol.13, No.1 (2013), pp.93-99.

加藤徹也，ものの壊れかた一破断に至る変形の観察に基づく「力」の導入法一, 千葉大学教育学部研究紀要, Vol.54 (2006), pp.285-291.

Kenney, R. and Richards, M.W., Photoelastic stress patterns produced by implant-retained overdentures, The Journal of Prosthetic Dentistry, Vol.80, No.5 (1998), pp.559-564.

室谷心, 光の 3 原色と黒体幅射, 物理教育, Vol.60, No.2 (2012), pp.110-114.

Sato, T., Mamiya, H., Koike, H. and Fukuchi, K., Photoelastic touch: Transparent rubbery tangible interface using an LCD and photoelasticity, Proceedings on the 22nd Annual ACM Symposium on User Interface Software and Technology (UIST'09) (2009), pp.43-50.

Shakerin, S. and Jensen, D.D., Enhancement of mechanics education by means of photoelasticity and finite element method, International Journal of Mechanical Engineering Education, Vol.29, No.4 (2001), pp.307-320.

白石哲郎, 曽山義朗, 低 $\Delta \mathrm{K}$ 領域におけるポリカーボネートの疲労き裂進展挙動に及ぼす応力比の影響, 材料, Vol.33, No.373 (1984), pp.1311-1316.

鈴木新一, 山口徹, 吉武春樹, 成田紘之, 光弾性法を用いたプラスチックメガネレンズのひずみ測定，実験力学， Vol.10, No.2 (2010), pp.193-197.

鈴木新一, 村井大我, 西北昇平, 片山陽太, 光弾性法を用いた自動車用電球の残留応力測定, 実験力学, Vol.11, No.3 (2011), pp.188-194.

S. ティモシェンコ, 鵜戸口英善, 国尾武, 材料力学 上巻 (1977),pp.88-92, 東京図書株式会社.

辻二郎, 西田正孝, 河田幸三，光弾性実験法 (1975), 日刊工業新聞社.

梅崎栄作, 光弾性法による応力分布測定技術の現状と展望, 精密工学会誌, Vol. 79, No. 7 (2013), pp. 607-611.

若林文高, 液晶ディスプレイを用いた光弾性，旋光性の観察(私のくふう), 科学と教育, Vol.54, No.2 (2006), pp.122-123.

山川昌文, 早川伸哉, 中村隆, 長谷川達也, 熱可塑性樹脂のレーザ溶着における温度と光弾性縞の同時観察, 日本 機械学会論文集 C 編, Vol.75, No.750 (2009), pp.491-495.

\section{References}

Brosh, T., Pilo, R. and Sudai, D., The influence of abutment angulation on strains and stresses along the implant/bone interface: Comparison between two experimental, The Journal of Prosthetic Dentistry, Vol.79, No.3 (1998), pp.328-334.

Christopher, C.J., James, M.N, Patterson, E.A. and Tee, K.F., A quantitative evaluation of fatigue crack shielding forces using photoelasticity, Engineering Fracture Mechanics, Vol.75 (2008), pp.4190-4199.

Fujikake, H., Recent technology and challenge on liquid crystal materials and displays, Journal of the Illuminating Engineering Institute of Japan, Vol.92, No.10 (2008), pp.721-728 (in Japanese).

Hirokawa, S., Lawi, A., Sekiya, K. and Takiguchi, J., Photoelastic study of contact stress on the tibial insert of knee prosthesis for high/deep flexion, Transactions of the Japan Society of Mechanical Engineers, Series C, Vol.75, No.752 (2009), pp. 1016-1025 (in Japanese).

Ikeda, S., Okada, Y., Fukuda, T., Arai, F., Negoro, M. and Takahashi, I., Patient-tailored cerebral artery model for simulating neurovascular intervention : 3rd report, photoelastic stress measurement on vascular wall under simulated operations, Transactions of the Japan Society of Mechanical Engineers, Series C, Vol.74, No.743 (2008), pp.1914-1919 (in Japanese).

Ito, H., Nishimura, K. and Ezumi, T., Influence of mechanical properties of inclusion on deformation of crack tip in rotating disc : experimental examination by photoelasticity and method of caustics, Transactions of the Japan Society of Mechanical Engineers, Series A, Vol.70, No.699 (2004), pp.1609-1615 (in Japanese).

Imai, T., Shida, N., Suga, K. and Iida, T., Study on control of birefringence for a thin disk replication, PIONEER R\&D, Vol.10, No.3 (2000), pp.22-28 (in Japanese).

Kakunai, S., Tokuda, N., Kaneko, H. and Nishimura, J., Influence of lens clamping on lens strain of spectacles, Journal of the Japanese Society for Experimental Mechanics, Vol.13, No. 1 (2013), pp.93-99 (in Japanese). 
Kato, T., An introduction to force with the observation of inhomogeneous deformation at the intended break, Chiba University's Repository for Access to Outcomes from Research, Vol.54 (2006), pp.285-291 (in Japanese).

Kenney, R. and Richards, M.W., Photoelastic stress patterns produced by implant-retained overdentures, The Journal of Prosthetic Dentistry, Vol.80, No.5 (1998), pp.559-564.

Muroya, S., The three primary colors and the black-body radiation, Physics Education Society of Japan, Vol.60, No.2 (2012) pp.110-114 (in Japanese).

Sato, T., Mamiya, H., Koike, H. and Fukuchi, K., Photoelastic touch: Transparent rubbery tangible interface using an LCD and photoelasticity, Proceedings on the 22nd Annual ACM Symposium on User Interface Software and Technology (UIST'09) (2009), pp.43-50.

Shakerin, S. and Jensen, D.D., Enhancement of mechanics education by means of photoelasticity and finite element method, International Journal of Mechanical Engineering Education, Vol.29, No.4 (2001), pp.307-320.

Shiraishi, T. and Soyama, Y., Effect of stress ratio on fatigue crack propagation behavior of polycarbonate at low stress intensity factor range level, Journal of the Society of Materials Science, Japan, Vol.33, No.373 (1984), pp.1311-1316 (in Japanese).

Suzuki, S., Yamaguchi, T., Yoshitake, H. and Narita, H., Strain measurement of plastic lens for glasses by phtoelasticity, Journal of the Japanese Society for Experimental Mechanics, Vol.10, No. 2 (2010), pp.193-197 (in Japanese).

Suzuki, S., Murai, T., Nishikita, S. and Katayama, Y., Measurement of residual stress of light bulbs for automobiles by photoelasticity, Journal of the Japanese Society for Experimental Mechanics, Vol.11, No. 3 (2011), pp.188-194 (in Japanese).

Timoshenko, S., Udoguchi, T. and Kunio, T., mechanics of materials the first volume, pp.88-92 (1977), TokyoTosho Co.,Ltd (in Japanese).

Tsuji, J., Nishida, M. and Kawata, K., Experimental methods in photoelasticity (1975), THE NIKKAN KOGYO SHIMBUN,LTD. (in Japanese).

Umezaki, E., Stress distribution measurement techniques using photoelasticity : Current status and future prospects, Journal of the Japan Society for Precision Engineering, Vol. 79, No.7 (2013), pp. 607-611 (in Japanese).

Wakabayashi, F., Observation of optical elasticity and rotation using LCD, Chemical Education, Vol.54, No.2 (2006), pp.122-123 (in Japanese).

Yamakawa, M., Hayakawa, S., Nakamura, T. and Hasegawa, T., Simultaneous observation of temperature and photoelastic fringes in laser welding of thermoplastic resin plates, Transactions of the Japan Society of Mechanical Engineers, Series C, Vol.75, No.750 (2009), pp.491-495 (in Japanese). 